\title{
Preferensi Nasabah Memilih Produk Pembiayaan Bank Aceh Syariah di Kota Banda Aceh
}

\author{
Khairul Amri \\ Fakultas Ekonomi dan Bisnis Islam Universitas Islam Negeri Ar-Raniry \\ e-mail:khairul.amri@ar-raniry.ac.id \\ Intan Qurratul'aini \\ Fakultas Ekonomi dan Bisnis Islam Universitas Islam Negeri Ar-Raniry \\ e-mail:intan2006@gmail.com \\ Julianty \\ Madrasah Ibtidaiyah Negeri (MIN) 2 Banda Aceh \\ e-mail: juliantyismail96@yahoo.com
}

\begin{abstract}
Abstrak
Penelitian ini bertujuan untuk menganalisis preferensi nasabah dalam memilih produk pembiayaan Bank Aceh Syariah di Kota Banda Aceh. Preferensi yang dimaksudkan terdiri dari manfaat ekonomi, lokasi bank, sesuai dengan keyakinan, konsep bagi hasil, pemahaman agama, informasi publik dan lingkungan nasabah. Sampel penelitian sebanyak 100 orang nasabah yang diambil secara purposive sampling. Pengumpulan data menggunakan kuesioner dan selanjutnya data dianalisis dengan menggunakan statistik deskriptif dan statistik inferensi Uji MannWhitney. Penelitian menemukan bahwa lingkungan menjadi preferensi paling dominan bagi nasabah dalam memilih produk pembiayaan Bank Aceh Syariah. Berikutnya, kesesuaian dengan keyakinan dan lokasi bank di urutan kedua. Sebaliknya manfaat ekonomi berada urutan terakhir. Hasil uji Man-Whitney mengindikasikan perbedaan jenis kelamin, umur, status perkawinan dan tingkat pendidikan tidak menyebabkan adanya perbedaan preferensi nasabah dalam memilih produk pembiayaan Bank Aceh Syariah. Artinya, preferensi nasabah tidak berbeda berdasarkan jenis kelamin, umur, status perkawinan dan tingkat pendidikan. Sebaliknya perbedaan pekerjaan dan pendapatan rata-rata per bulan menyebabkan perbedaan preferensi nasabah memilih produk pembiayaan bank syariah.
\end{abstract}

Kata kunci: Produk pembiayaan, preferensi nasabah, Uji Mann-Whitney.

\section{PENDAHULUAN}

Lahirnya bank syariah dengan prinsip bagi hasil (profit loss sharing) didasarkan pada dua alasan utama, yaitu (1)adanya pandangan bahwa bunga (interest) pada bank konvensional hukumnya haram karena termasuk dalam kategori riba yang dilarang dalam agama, bukan saja pada agama Islam tetapi juga oleh agama samawi lainnya; dan (2)dari aspek ekonomi, penyerahan resiko usaha terhadap salah satu pihak dinilai melanggar norma keadilan. Dalam jangka panjang sistem perbankan konvensional akan menyebabkan penumpukan kekayaan pada segelintir orang yang memiliki kapital besar. Faktor utama yang membedakan bank konvensional dengan bank syariah adalah suku bunga (interest) sebagai balas jasa atas penyertaan modal yang diterapkan pada bank konvensional, sementara pada bank syariah balas jasa atas modal diperhitungkan berdasarkan keuntungan atau kerugian yang diperoleh didasarkan pada "akad". Prinsip utama dari "akad" ini adalah keadilan antara 
pemberi modal dan pemakai modal. Prinsip ini berlaku baik bagi debitur maupun kreditur.

Sebagai proses pengambilan keputusan, perilaku seseorang untuk menjadi nasabah suatu bank dapat dipengaruhi oleh faktor intern seperti sikap, persepsi, motivasi, dan faktor ekstern seperti pengaruh kelompok referensi, pendidikan, kondisi sosial dan keluarga. Disamping itu, dari pihak bank ada beberapa akibat maupun faktor yang dapat mempengaruhi preferensi maupun perilaku nasabah untuk menjadi nasabah di suatu bank. Seperti lokasi bank di kawasan strategis, segala sarana dan prasarana yang eksklusif yang memberikan kenyamanan, pelayanan yang cepat dan ramah, keamanan berinvestasi serta keuntungan yang akan diberikan. Dengan mengetahui alasan-alasan nasabah memutuskan untuk menjadi nasabah bank, pihak bank akan mendapat gambaran mengenai siapa nasabahnya, untuk keperluan apa, maupun siapa mereka.

Secara teoritis, potensi pasar Bank Aceh Syariah di Aceh sangat besar. Hal ini tidak terlepas dari nilai-nilai dan norma-norma yang dianut dan dijunjung tinggi oleh masyarakat Aceh sendiri yang sangat kental dengan nilai dan norma keislaman. Ditambah lagi dengan adanya penerapan syariat Islam diharapkan dapat mempertinggi keinginan dan kesadaran masyarakat untuk menerapkan prinsip-prinsip syariah di dalam kehidupan sehari-hari, termasuk urusan mu'amalah yang dipraktekkan oleh dunia perbankan.

Sebagai respon terhadap pentingnya pelaksanaan prinsip-prinsip syariah di kalangan masyarakat Aceh, maka Pemerintah Aceh melakukan konversi Bank Aceh yang sebelumnya dioperasionalkan dengan prinsipprinsip konvensional menjadi Bank Aceh Syariah. Mulai tanggal 19 September 2016 Bank Aceh mulai beroperasi sebagai Bank Umum Syariah. Sejak itu produk pembiayaan yang ditawarkan Bank Aceh Syariah kepada masyarakat juga sudah menyesuaikan dengan prinsip-prinsip pembiayaan syariah. Hingga saat ini produk pembiayaan Bank Aceh Syariah terdiri dari pembiayaan Murabahah, Musyarakah, Mudharabah, Istishna, Salam,
Qardhul Hasan, Rahn, Wakalah dan pembiayaan Ijarah.

Pemahaman perilaku nasabah terkait pembiayaan syariah secara baik adalah sesuatu yang penting untuk keputusan pemasaran yang tepat dalam lingkup yang lebih luas. Untuk menghadapi persaingan dan memperluas pasar, maka perilaku nasabah terutama berhubungan dengan preferensi seseorang memutuskan untuk menjadi nasabah pembiayaan pada Bank Aceh Syariah sangat penting untuk diketahui dan dipahami. Apalagi preferensi seseorang terkait dengan berbagai faktor terutama karakteristik demografi yang melekat pada orang tersebut (Simamora, 2004).

Hingga saat ini sudah terdapat banyak penelitian yang berkaitan dengan preferensi nasabah memilih bank syraiah. Norafifah dan Haron yang dikutip oleh Kurniati (2012) menyimpulkan bahwa preferensi konsumen terhadap Bank Syariah terdiri dari beberapa dimensi, antara lain pemanfaatan fasilitas perbankan dan pengetahuan terhadap perbankan Islam.

Sebelumnya, hasil penelitian yang dilakukan Bank Indonesia dan Pusat Penelitian Kajian Pembangunan Lembaga Penelitian Universitas Diponegoro Semarang (2000) tentang potensi, preferensi dan perilaku masyarakat terhadap Bank Syariah, antara lain menyimpulkan bahwa faktorfaktor yang mempengaruhi masyarakat menggunakan jasa bank syariah adalah lokasi/ akses, pelayanan, kredibilitas, fasilitas, status, dan pengetahuan nasabah tentang Bank Syariah. Kesimpulan umum dari riset ini adalah bahwa masyarakat memilih bank syariah lebih karena faktor ekonomis. Penelitian terbaru dilakukan oleh Majid dan Zulhanizar (2016) tentang perilaku nasabah bank syariah di Aceh antara lain menyimpulkan bahwa pemilihan bank syariah oleh nasabah dipengaruhi oleh tiga faktor penting, yaitu karakteristik bank, pelayananan kepercayaan, shari'ah compliance, dan fasilitas/objek fisik.

Berbeda dengan penelitian-penelitian sebelumnya, fokus kajian pada artikel ini adalah preferensi nasabah Bank Aceh Syariah 
dalam memilih produk pembiayaan bank. Secara spesifik, artikel ini menganalisis preferensi nasabah terhadap produk pembiayaan Bank Aceh Syariah yang mencakup ada tidaknya perbedaan preferensi nasabah terhadap produk pembiayaan berdasarkan karakteristik demografis (jenis kelamin, usia, status perkawinan, tingkat pendidikan, pekerjaan, dan pendapatan ratarata per bulan), serta atribut produk pembiayaan syariah mana yang lebih dominan mempengaruhi keputusan nasabah untuk menggunakan produk pembiayaan pada bank tersebut.

\section{Konsep Preferensi Konsumen}

Preferensi konsumen adalah pilihanpilihan atau penilaian-penilaian berdasarkan rangking terhadap atribut produk/jasa yang dilakukan oleh konsumen melalui trading off features, satu terhadap yang lain (Koo et al., 1999). Preferensi seseorang terhadap suatu objek adalah keinginan atau kecenderungan seseorang untuk memilih atau tidak memilih objek tersebut yang dipengaruhi oleh variabel-variabel tertentu.

Anonymous (2006) mendefinisikan preferensi sebagai sejauhmana seseorang lebih suka menfokuskan perhatian. Ada dua arah yang berlawanan kemana seseorang individu dapat memfokuskan perhatian, yaitu ke arah dunia diluar dirinya (extroversion), atau ke arah dunia didalam dirinya (introversion). Orang yang lebih menyukai extroversion cenderung untuk memfokuskan perhatiannya kepada dunia di luar dirinya, yaitu terhadap orang-orang sekelilingnya dan kejadian-kejadian disekitarnya. Ketika sedang melaksanakan extroversion dia akan sangat bergairah terhadap apa yang sedang berlangsung disekitarnya, dan inilah yang akan menimbulkan kecenderungan ke arah mana dia mengarahkan perhatian dan energinya. Orang extrovert lebih menyukai berkomunikasi melalui kata-kata daripada dengan tulisan. Mereka akan lebih mudah memahami sesuatu setelah mengalaminya terlebih dahulu, oleh sebab itu mereka adalah orang yang menyukai tindakan daripada ide/pemikiran (action oriented).
Selanjutnya, orang yang lebih menyukai introversion cenderung untuk memfokuskan perhatiannya ke dalam dunia pemikirannya sendiri. Pada saat mereka sedang melakukan introversion, mereka bergairah terhadap apa yang sedang bergolak di dalam pemikirannya, dan kondisi inilah yang akan menimbulkan kecenderungan untuk mengarahkan perhatian dan energinya terhadap pemikiran tersebut. Orang yang introvert cenderung untuk merasa lebih nyaman dan tertarik apabila menghadapi suatu pekerjaan yang menuntut pembahasan dan pemikiran yang dapat dilakukan sendiri secara tenang. Mereka cenderung untuk mencoba mengerti dan memahami sesuatu sebelum mencoba atau mengalaminya. Oleh karena itu, mereka cenderung untuk selalu berfikir terlebih dahulu sebelum mengambil tindakan.

Preferensi masyarakat dalam memilih produk pembiayaan syariah misalnya, sangat bervariasi. Hal ini karena setiap individu yang dalam hal ini adalah nasabah memiliki keinginan yang berbeda-beda. Namun secara umum, tingkat preferensi nasabah tersebut dapat diperoleh berdasarkan faktor-faktor (internal dan eksternal) yang menjadi dasar pertimbangan pemilihan suatu produk pembiayaan.

\section{Literatur Empiris}

Metawa dan Almossawi (1998) melakukan penelitian tentang keputusan nasabah menggunakan produk bank syariah di Bahrain. Penelitian tersebut antara lain menyimpulkan bahwa keputusan nasabah dalam menggunakan produk bank syariah adalah lebih didorong oleh faktor agama, yaitu ketaatannya pada prinsip-prinsip ajaran Islam. Riset Erol dan El-Bdour (1989) menemukan bahwa motif nasabah dalam memilih bank syariah didasarkan pada motif keuntungan, dan bukan motif agama. Selain itu, peer group, kesadaran nasabah terhadap keuntungan yang diperoleh melalui investasi profit/loss sharing, serta distribusi pendapatan sistem bank syariah juga mempengaruhi keputusan memilih bank syariah. Haron dan Norafifah (2000) dalam penelitiannya di Malaysia menemukan hubungan positif antara 
simpanan yang ada di bank syariah dan tingkat keuntungannya. Secara ringkas, riset tersebut menyimpulkan bahwa faktor yang mendorong nasabah menyimpan uangnya di bank syariah adalah motivasi mencari keuntungan atau faktor ekonomis.

Naser et al. (1999) menggunakan sampel sebanyak 206 nasabah bank syariah di Yordania untuk meneliti bagaimana kesadaran dan kepuasan nasabah terhadap produk dan fasilitas bank syariah. Hasilnya menunjukkan meskipun nasabah sadar akan produk dan fasilitas yang ditawarkan bank syariah seperti murabahah, musyarakah, dan mudharabah, namun tanggapan nasabah mengindikasikan belum puas atas produk dan fasilitas yang tersedia. Kemudian, faktor yang mendorong nasabah memilih bak syariah adalah faktor reputasi bank, alasan agama, prinsip syariah yang digunakan, kemampuan bank menjaga kerahasiaan, alasan agama, dan alasan keuntungan.

Gerrad dan Cunningham (1997) melalui studi empirisnya di Singapura dengan menggunakan 190 responden, menemukan bahwa sikap muslim dan non muslim dalam memilih bank syariah secara signifikan tidak berbeda. Yang mendorong mereka memilih bank syariah adalah pelayanan yang cepat dan efisien, kerahasiaan bank, reputasi dan citra bank, ringannya biaya cek, dan tersedianya tempat parkir. Disimpulkan bahwa mereka memilih bank syariah didasarkan pada faktor ekonomis dan agama.

Hasil penelitian kerjasama Bank Indonesia dan Institut Pertanian Bogor (2000) tentang bank syariah di wilayah Jawa Barat menunjukkan bahwa faktor-faktor yang mempengaruhi masyarakat menggunakan jasa bank syariah adalah lokasi/akses, pelayanan, kredibilitas, fasilitas, status, dan pengetahuan nasabah tentang bank syariah. Kesimpulan umum dari riset ini adalah bahwa masyarakat memilih dan menggunakan produk bank syariah lebih karena faktor ekonomis.

Rezwan et al (2015) meneliti sikap nasabah terhadap bank syariah dan bank konvensional di Bangladesh. Variabel yang digunakan untuk mengkaji sikap nasabah adalah teknologi, reputasi, benefit dan service, dan perspektif religius. Penelitian tersebut menyimpulkan bahwa sikap nasabah terhadap bank Islam adalah lebih baik bila dibandingkan dengan sikap nasabah terhadap bank konvensional.

\section{Kerangka Pemikiran}

Pemilihan produk jasa perbankan oleh nasabah tidak terlepas dari berbagai kemudahan yang ditawarkan oleh produk perbankan itu sendiri. Selain itu, pemilihan produk jasa perbankan sebagaimana halnya produk pembiayaan Bank Aceh Syariah yang didasarkan pada nilai-nilai syari'ah, juga didasarkan pada nilai-nilai dan norma-norma yang dianut oleh masyarakat. Nilai-nilai dan norma-norma yang dimaksudkan dalam penelitian ini adalah nilai-nilai dan normanorma ke-Islaman yang sudah berlaku umum dikalangan masyarakat Kota Banda Aceh. Hal ini didasarkan pada kenyataan bahwa salah satu alasan dikembangkannya produk syariah adalah untuk memberikan pilihan kepada masyarakat untuk memanfaatkan jasa perbankan yang dalam prakteknya sesuai dengan ajaran dan norma agama Islam itu sendiri. Mengacu pada penelitian penelitian sebelumnya, maka preferensi nasabah yang dimaksudkan dalam penelitian ini meliputi manfaat ekonomi, lokasi bank, keamanan uang, kesesuaian dengan keyakinan, konsep bagi hasil, pemahaman agama, informasi publik dan lingkungan nasabah.

Secara umum, nasabah menginginkan adanya manfaat ekonomi dari keputusan yang mereka ambil dalam memanfaatkan produk pembiayaan syariah. Manfaat ekonomi yang dimaksudkan tentunya nilai tambah dari kepemilikan asset yang mereka kembangkan dengan adanya produk pembiayaan yang mereka pilih. Lokasi bank juga dapat menjadi preferensi bagi nasabah karena menyangkut dengan kemudahan transportasi dalam mengunjungi bank tersebut.

Selanjutnya, kesesuaian antara nilainilai keyakinan yang dianut oleh nasabah dengan produk yang ditawarkan juga menjadi acuan bagi nasabah untuk memilih produk pembiayaan syariah. Konsep bagi hasil yang ditawarkan oleh pembiayaan syariah dinilai 
lebih mampu menjauhkan nasabah dari praktek bunga yang oleh sebagian kalangan dinilai mengandung unsur ribah. Karena itu, pemahaman agama, informasi publik dan lingkungan nasabah juga dapat menjadi preferensi dalam memilih produk pembiayaan syariah.

Selain itu, faktor lain yang dapat membedakan preferensi nasabah adalah karakteristik nasabah itu sendiri. Karakteristik seseorang mempengaruhi pembentukan preferensi karena memiliki cara dan kemampuan yang berbeda dalam membentuk persepsi. Informasi apa yang diinginkan, bagaimana menginter pretasikan informasi tersebut dan informasi apa yang diingat, tergantung dari karakteristik individu, seperti tingkat pendidikan, umur, jenis kelamin, keperibadian dan lain-lain (Simamora, 2004). Karakteristik nasabah terutama latar belakang pendidikan (mengerti atau tidak mengerti tentang prinsip syariah) juga akan dapat menjadi membedakan pandangan mereka terhadap produk pembiayaan syariah itu sendiri, begitu juga halnya dengan tingkatan usia, dan lain sebagainya.

Mengacu pada uraian di atas, maka paradigma penelitian seperti ditunjukkan dalam Gambar 1.

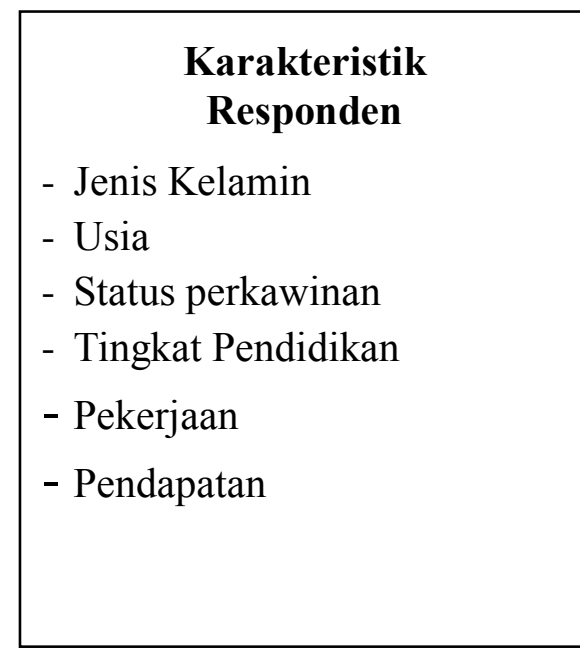

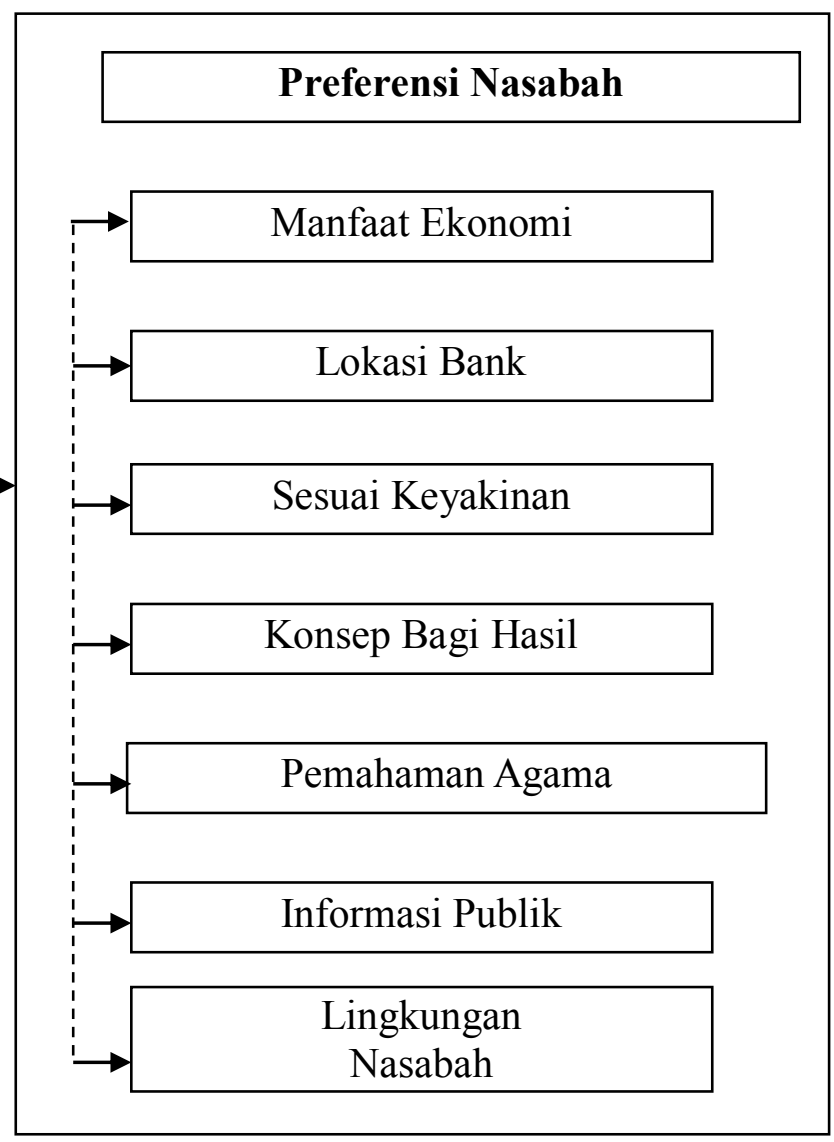

Sumber: Diolah Peneliti, Tahun 2017.

\section{Gambar 1. Paradigma Penelitian}

\section{METODE PENELITIAN}

\section{Populasi dan Penarikan Sampel}

Populasi penelitian adalah nasabah PT. Bank Aceh Syariah di Banda Aceh yang menjadi nasabah produk pembiayaan (mudharabah, musyarakah, dan murabahah) tahun 2017. Sampel penelitian sebanyak 100 orang nasabah yang diambil secara proporsional sampling dari tiga jenis pembiayaan tersebut. Penarikan seseorang nasabah untuk dijadikan sampel penelitian dilakukan secara purposive sampling dengan 
ketentuan selain menjadi nasabah pembiayaan Bank Aceh Syariah, seseorang nasabah juga sudah pernah menjadi nasabah kredit/nasabah pembiayaan bank lain selain Bank Aceh Syariah.

\section{Operasional Variabel, Pengumpulan Data dan Skala Pengukuran}

Operasional variabel penelitian ini adalah prefensi nasabah dalam memilih pembiayaan syariah yang meliputi manfaat ekonomi, lokasi bank, sesuai dengan keyakinan, konsep bagi hasil, pemahaman agama, informasi publik dan lingkungan nasabah. Selain itu, sesuai dengan tujuan penelitian, karakteristik sosial demografis yang meliputi jenis kelamin, usia, status perkawinan, tingkat pendidikan, pekerjaan dan pendapatan juga merupakan operasional variabel.

Pengumpulan data dilakukan dengan mengedarkan kuesioner berisi pernyataan yang berhubungan dengan operasional varibel seperti dijelaskan sebelumnya. Masingmasing pernyataan disediakan alternatif pilihan jawaban dalam tingkat kesetujuan. Nasabah diminta untuk memberikan respon terhadap masing-masing pernyataan terkait dengan memilih salah satu alternatif pilihan jawaban yang paling cocok. Selain itu, kuesioner penelitian juga berisi informasi mengenai karakteristik nasabah yang meliputi jenis kelamin, umur, status perkawinan, latar belakang pendidikan, pekerjaan, pendapatan rata-rata perbulan dan lain sebagainya.

Skala pengukuran data yang digunakan terdiri dari skala nominal/katagori dan skala Likert. Skala nominal digunakan untuk memberikan skor terhadap data yang berhubungan dengan karakteristik responden. Seperti halnya jenis kelamin, laki-laki diberi skor 1, dan perempuan diberi skor 2 . Demikian pula halnya dengan karakteristik demografi lainnya seperti tingkatan usia, tingkat pendidikan, pekerjaan, pendapatan dan lain sebagainya, pemberian skor menggunakan skala nominal/katagori. Selanjutnya skala Likert digunakan untuk memberikan skor terhadap alternatif pilihan/tingkat kesetujuan responden terhadap masing-masing pernyataan yang berkaitan dengan preferensi nasabah memilih Bank Aceh Syariah. Skala tersebut berkisar antara $1-5$, dengan ketentuan $1=$ tidak setuju, $2=$ kurang setuju, 3 = ragu-ragu, $4=$ setuju, dan $5=$ sangat setuju.

\section{Metode Analisis Data}

Metode analisis data yang digunakan dalam penelitian ini terdiri dari statistik deskriptif dan statistik infrensial.

Statistik deskriptif digunakan untuk menganalisis setiap variabel penelitian secara terpisah, sehingga analisis ini bersifat hanya memaparkan temuan hasil penelitian secara terpisah tanpa melihat keterkaitan variabel itu dengan variabel lainnya. Pendeskripsian hasil penelitian dilakukan dengan persentase dan metode rata-rata. Peralatan ini dinilai lebih tepat untuk menjelaskan atribut produk pembiayaan Bank Syariah yang lebih dominan mempengaruhi keputusan nasabah menggunakan produk pembiayaan bank itu.

Statistik inferensial digunakan untuk melihat keterkaitan antara satu variabel dengan variabel lainnya, sesuai dengan tujuan penelitian yaitu untuk mengetahui apakah terdapat perbedaan preferensi nasabah terhadap produk pembiayaan berdasarkan karakteristiknya. Karena data yang diperoleh tidak akan memenuhi asumsi normalitas, maka metode statistik inferensial yang digunakan adalah statistik non parametrik, dalam hal ini adalah uji Mann-Whitney yang lebih dikenal juga dengan U-Tes. Uji MannWhitney dirumuskan sebagai berikut:

$$
Z=\frac{U-n_{1} n_{2} / 2}{\sqrt{n_{1} n_{2}\left(n_{1}+n_{2}+1\right) / 12}},
$$

Nilai $U$ dicari dengan rumus :

$$
\mathrm{U}=\mathrm{n}_{1} \mathrm{n}_{2}+\mathrm{n}_{1}\left(\mathrm{n}_{1}+1\right) / 2-\sum R_{1}
$$

dimana $U$ adalah Nilai U-test; R adalah skor alternatif pilihan jawaban terhadap variabel preferensi; $\mathrm{n}_{1}$ adalah jumlah populasi yang termasuk dalam kelompok sosial demografis pertama; dan, $\mathrm{n}_{2}$ adalah jumlah populasi yang termasuk dalam kelompok sosial demografis kedua. 
Pengujian ada atau tidaknya perbedaan preferensi nasabah berdasarkan karakteristik demografi, didasarkan pada perbandingan nilai Z-hitung (yang diperoleh dengan rumus seperti ditunjukkan di atas), dengan nilai kritis $\mathrm{Z}$ untuk dua ekor (two-tailed) pada tingkat keyakinan 95 persen. Ketentuan pengujian sebagai berikut.

- Apabila besaran nilai statistik hitung lebih besar dibandingkan dengan nilai statistik tabel (Z-hitung $>$ Z-tabel), berarti terdapat perbedaan preferensi nasabah atas produk pembiayaan berdasarkan karakteristiknya.

- Apabila besaran nilai statistik hitung lebih kecil dibandingkan nilai statistik tabel (Zhitung $>$ Z-tabel), berarti tidak terdapat perbedaan preferensi nasabah atas produk pembiayaan berdasarkan karakteristiknya.

\section{HASIL ANALISIS}

Preferensi nasabah dalam memilih produk pembiayaan Bank Aceh Syariah didekati dengan penilaian mereka terhadap tujuh faktor terdiri dari manfaat ekonomi, lokasi bank, keseuaian dengan keyakinan, konsep bagi hasil, pemahaman agama, informasi publik, dan lingkungan nasabah. Berdasarkan hasil pengolahan data, diantara tujuh faktor tersebut, lingkungan nasabah merupakan preferensi sangat menentukan bila dibandingkan dengan indikator lain. Hal ini disebabkan nilai rerata skor tingkat kesetujuan responden terhadap indikator lingkungan nasabah sebesar 4,017 lebih besar apabila dibandingkan dengan 6 (enam) faktor lainnya.
Dengan demikian, ada kecenderungan atau preferensi utama nasabah dalam memanfaatkan produk pembiayaan Bank Aceh Syariah adalah faktor lingkungan nasabah itu sendiri. Pada umumnya mereka berasal dari kalangan keluarga yang tahu banyak tentang prinsip-prinsip syariah yang sesuai dengan ajaran Islam. Situasi itu menyebabkan keputusan untuk memanfaatkan produk pembiayaan bank syariah tersebut tidak terlepas dari nilai-nilai fanatisme keislaman yang dianut oleh keluarga mereka, terutama dalam urusan ekonomi atau mu'amalah.

Tabel 1 memperlihatkan nilai rerata skor tingkat kesetujuan nasabah atas pernyataan yang berhubungan dengan tujuh faktor penting dalam memilih produk pembiayaan Bank Aceh Syariah sebagai tolok ukur preferensi mereka dalam memanfaatkan produk pembiayaan tersebut. Setelah faktor lingkungan nasabah sebagai preferensi utama dalam memilih produk pembiayaan Bank Aceh Syariah, faktor berikutnya adalah kesesuaian dengan keyakinan dan lokasi bank dengan nilai rata-rata skor masing-masing sebesar sebesar 3,937. Kemudian menyusul konsep bagi hasil dengan nilai rata-rata skor sebesar 3,930. Selanjutnya konsep bagi hasil berada pada urutan keempat dengan nilai ratarata skor sebesar 3,917. Faktor manfaat ekonomi merupakan preferensi yang dianggap paling lemah, dengan nilai rerata skor tingkat kesetujuan paling kecil di antara tujuh faktor tersebut, yaitu sebesar 3,932.

Tabel 1. Deskripsi Preferensi Nasabah Memilih Produk Pembiayaan Bank Aceh Syariah

\begin{tabular}{|c|c|c|c|}
\hline No. & Preferensi Nasabah & Nilai Rerata Skor & Keterangan Preferensi \\
\hline 1. & Manfaat ekonomi & 3,863 & \multirow{7}{*}{$\begin{array}{l}\text { Preferensi Paling menentukan } \\
\text { diantara semua preferensi adalah } \\
\text { lingkungan nasabah, kemudian } \\
\text { diikuti oleh kesesuaian dengan } \\
\text { keyakinan, pemahaman agama } \\
\text { dan konsep bagi hasil. }\end{array}$} \\
\hline 2. & Lokasi bank & 3,937 & \\
\hline 3. & Kesesuaian dengan keyakinan & 3,937 & \\
\hline 4. & Konsep bagi hasil & 3,930 & \\
\hline 5. & Pemahaman agama & 3,917 & \\
\hline 6. & Informasi publik & 3,893 & \\
\hline 7. & Lingkungan nasabah & 4,017 & \\
\hline
\end{tabular}

Sumber: Data primer (diolah), Tahun 2017. 


\section{Analisis Perbedaan Preferensi Nasabah Terhadap Produk Pembiayaan Bank Aceh Syariah di Kota Banda Aceh}

Preferensi nasabah dalam memilih produk pembiayaan yang ditawarkan oleh Bank Aceh Syariah tentunya tidak terlepas dari karakteristik nasabah itu sendiri. Karakteristik seseorang mempengaruhi pembentukan preferensi karena memiliki cara dan kemampuan yang berbeda dalam membentuk persepsi (Simamora, 2004). Karakteristik nasabah terutama latar belakang pendidikan juga dapat menjadi membedakan pandangan mereka atas produk pembiayaan syariah itu sendiri, begitu juga halnya dengan tingkatan usia, dan lain sebagainya. Karena itu, dalam penelitian ini kajian terhadap perbedaan preferensi nasabah dalam memilih produk pembiayaan Bank Aceh Syariah dinilai perlu dilakukan. Setidaknya informasi tersebut dapat menjadi masukan bagi pihak manajemen Bank Aceh Syariah dalam mengetahui preferensi nasabah terhadap produk pembiayaan yang mereka tawarkan kepada masyarakat.

Karakteristik demografis nasabah yang dimaksudkan dalam penelitian ini terdiri dari jenis kelamin, usia, status perkawinan, tingkat pendidikan, pekerjaan dan pendapatan ratarata per bulan. Peralatan analisis data yang digunakan untuk mengetahui ada atau tidak adanya perbedaan preferensi nasabah berdasarkan karakteristik demografis tersebut adalah statistik non parametrik Mann-Whitney Test. Penggunaan teknik statistik tersebut membutuhkan perhitungan matematis di dalamnya, sehingga data yang digunakan minimal berskala interval. Karena itu, sebelum dilakukan pengolahan data dengan menggunakan peralatan statistik, terlebih dahulu dilakukan proses transformasi data skala Likert (berupa skor pilihan jawaban responden atas masing-masing pernyataan) yang pada dasarnya adalah berskala ordinal, menjadi skala interval.

Pengujian apakah preferensi nasabah laki-laki berbeda dengan preferensi nasabah perempuan di dalam memilih produk pembiayaan Bank Aceh Syariah menunjukkan nilai Z-hitung sebesar -0,925. Pengujian dilakukan untuk dua sisi yang berarti adalah sisi kiri dan sisi kanan. Nilai kritis Z untuk tes dua sisi pada signifikansi $5 \%$ atau tingkat keyakinan sebesar 95 persen menunjukkan angka sebesar 1,96. Karena nilai Z-hitung < Z-tabel maka dapat diartikan preferensi nasabah laki-laki dalam memilih produk pembiayaan tidak berbeda signifikan dengan preferensi nasabah perempuan. Dengan kata lain, perbedaan jenis kelamin tidak membuat adanya perbedaan preferensi dalam memilih produk pembiayaan bank tersebut, sehingga dapat juga diinterpretasikan bahwa preferensi nasabah laki-laki dan perempuan relatif sama.

Selanjutnya untuk karakteristik umur, nasabah hanya dikelompokkan dalam dua kelompok umur yaitu dibawah 35 tahun dan di atas 35 tahun. Hal ini disebabkan uji MannWhitney hanya bisa digunakan untuk membedakan dua jenis kelompok data. Hasil pengujian menunjukkan nilai Z-hitung sebesar -0,035 juga lebih kecil bila dibandingkan dengan nilai kritis $\mathrm{Z}$ untuk tes dua sisi pada signifikansi $5 \%$ atau tingkat keyakinan sebesar 95 persen $(-0,035<1,96)$ juga dapat diartikan bahwa preferensi nasabah dengan usia di atas 35 tahun tidak berbeda signifikan dengan preferensi nasabah dengan usia dibawah 35 tahun. Artinya preferensi nasabah produk pembiayaan Bank Aceh Syariah yang menjadi responden tidak berbeda antara mereka berusia di atas 35 tahun dan mereka berusia dibawah 35 tahun.

Selanjutnya dilakukan uji beda apakah perbedaan status perkawinan dapat menyebabkan perbedaan preferensi terhadap nasabah menunjukkan nilai Z-hitung sebesar -0,393. Angka ini juga lebih kecil bila dibandingkan dengan harga kritis $\mathrm{Z}$ untuk tes dua sisi pada signifikansi $5 \%$ atau tingkat keyakinan sebesar 95 persen sebesar 1,96 $(-0,393<1,96)$. Dengan demikian dapat diartikan bahwa perbedaan status perkawinan tidak menimbulkan perbedaan preferensi dalam memilih produk pembiayaan Bank Aceh Syariah. Dengan kata lain, preferensi nasabah terhadap produk pembiayaan bank syariah tersebut tidak berbeda signifikan antara nasabah yang sudah menikah dengan nasabah yang belum menikah. 
Tabel 2. Hasil Uji Beda Rata-rata preferensi Nasabah Memilih Produk Pembiayaan Bank Aceh Syariah Berdasarkan Karakteristik Sosial Demografi

\begin{tabular}{|c|c|c|c|}
\hline $\begin{array}{c}\text { Karakteristik Sosial } \\
\text { Demografi }\end{array}$ & $\begin{array}{c}\text { Nilai } \\
\text { Z-hitung }\end{array}$ & $\begin{array}{c}\text { Harga Kritis Z } \\
\text { (Z-tabel) }\end{array}$ & Keterangan \\
\hline $\begin{array}{l}\text { Jenis Kelamin } \\
\text { - Laki-laki } \\
\text { - Perempuan } \\
\end{array}$ & $-0,925$ & 1,960 & Tidak berbeda signifikan \\
\hline $\begin{array}{l}\text { Usia } \\
-<35 \text { tahun } \\
->35 \text { tahun } \\
\end{array}$ & $-0,035$ & 1,960 & Tidak berbeda signifikan \\
\hline $\begin{array}{l}\text { Status Perkawinan } \\
\text { - Menikah } \\
\text { - Belum menikah }\end{array}$ & $-0,393$ & 1,960 & Tidak berbeda signifikan \\
\hline $\begin{array}{l}\text { Tingkat Pendidikan } \\
\text { - Perguruan tinggi } \\
\text { - Bukan perguruan tinggi }\end{array}$ & $-0,786$ & 1,960 & Tidak berbeda signifikan \\
\hline $\begin{array}{l}\text { Pekerjaan } \\
\text { - Wirausahawan/Pengusaha } \\
\text { - Bukan Wirausahawan/ Pengusaha }\end{array}$ & $-2,894$ & 1,960 & Berbeda signifikan \\
\hline $\begin{array}{l}\text { Pendapatan rata-rata perbulan } \\
-<\operatorname{Rp} 5.000 .000 \\
->\operatorname{Rp} 5.000 .000\end{array}$ & $-2,033$ & 1,960 & Berbeda signifikan \\
\hline
\end{tabular}

Sumber: Data primer (diolah), Tahun 2017.

Karakteristik responden selanjutnya tingkat pendidikan. Dalam hal ini, nasabah hanya dikelompokkan dalam dua kelompok tingkat pendidikan, yaitu mereka dengan latar belakang pendidikan perguruan tinggi dan mereka dengan latar belakang pendidikan bukan perguruan tinggi. Hasil pengujian uji beda rata-rata dengan peralatan statistik Mann-Whitney Test menunjukkan nilai Zhitung sebesar -0,786. Angka ini lebih kecil dari kritis $\mathrm{Z}$ untuk tes dua sisi pada signifikansi 5\%, sehingga dapat diartikan bahwa tidak terdapat perbedaan preferensi antara nasabah yang memiliki latar belakang perguruan tinggi dengan nasabah yang berasal dari latar belakang pendidikan bukan perguruan tinggi. Untuk lebih jelasnya mengenai hasil pengujian uji beda rata-rata preferensi nasabah dalam memilih produk pembiayaan Bank Aceh Syariah berdasarkan karakteristik sosial demografis dapat dilihat pada Tabel 2.

Selanjutnya dalam pengujian statistik responden dibedakan dalam dua kelompok pekerjaan, yaitu pengusaha dan bukan pengusaha. Hasil pengujian menunjukkan nilai Z-hitung sebesar -2,894 (dalam hal ini nilai negatif diabaikan karena pengujian dilakukan dua sisi). Angka ini lebih besar bila dibandingkan dengan nilai Z-tabel sebesar 1,960, sehingga dapat diartikan terdapat perbedaan preferensi nasabah memilih produk pembiayaan Bank Aceh Syariah berdasarkan jenis pekerjaan yang ditekuni. Dengan kata lain, nasabah yang dengan pekerjaan sebagai pengusaha/wiraswasta memiliki preferensi yang berbeda terhadap pembiayaan bank syariah itu dengan nasabah bila dibandingkan dengan nasabah dengan pekerjaan bukan pengusaha/wiraswasta.

Berdasarkan Tabel 2 juga dapat dilihat bahwa preferensi nasabah terhadap produk pembiayaan juga berbeda pendapatan ratarata per bulan. Preferensi nasabah yang memiliki pendapatan rata-rata relatif besar yaitu di atas dan dibawah Rp. 5.000.000,- per bulan dalam memiliki produk pembiayaan Bank Aceh Syariah berbeda signifikan dengan preferensi nasabah dengan pendapatan ratarata di bawah Rp. 5.000.000,- per bulan. 


\section{Implikasi Penelitian}

Temuan penelitian ini sedikit berbeda dengan temuan penelitian sebelumnya yang dilakukan oleh Khoirudin (2005) tentang preferensi nasabah terhadap produk pembiayaan (Mudharabah, Musyarakah, dan Murabahah) Bank Syariah di Yogyakarta yang menyimpulkan bahwa nasabah berdasarkan karakteristiknya (jenis kelamin, umur, pekerjaan, pendidikan terakhir, penghasilan per bulan) tidak mempunyai perbedaan preferensi terhadap semua atribut produk pembiayaan Bank Syariah. Kemudian, nasabah dengan berbagai kategori bentuk pembiayaan yang digunakan, memiliki perbedaan preferensi terhadap kesesuaian dengan keyakinan nasabah dan konsep bagi hasil yang ditawarkan dari produk pembiayaan Bank Syariah tersebut. Faktor kesesuaian dengan keyakinan dan manfaat ekonomi merupakan faktor yang paling mempengaruhi nasabah dalam menggunakan pembiayaan Bank Syariah.

Jika penelitian sebelumnya menemukan bahwa faktor yang paling mempengaruhi nasabah menggunakan pembiayaan Bank Syariah adalah faktor kesesuaian dengan keyakinan dan manfaat ekonomi, maka penelitian ini menemukan bahwa faktor yang paling mempengaruhi nasabah dalam memanfaatkan pembiayaan Bank Aceh Syariah adalah faktor lingkungan nasabah dan faktor kesesuaian dengan keyakinan. Dengan demikian, sekalipun temuan penelitian ini memiliki perbedaan dengan penelitian yang dilakukan oleh Khoirudin (2005), namun terdapat banyak persamaan, sehingga hasil penelitian ini dapat mendukung temuan empiris sebelumnya terkait dengan preferensi nasabah dalam memilih produk pembiayaan bank syariah.

\section{KESIMPULAN}

Berdasarkan hasil-hasil penelitian dan pembahasan yang telah dikemukakan, dapat ditarik beberapa kesimpulan.

Pertama, preferensi nasabah memilih produk pembiayaan Bank Aceh Syariah di kota Banda Aceh terdiri dari manfaat ekonomi, lokasi bank, kesesuaian dengan keyakinan, konsep bagi hasil, pemahaman agama, informasi publik, dan lingkungan nasabah. Antara tujuh faktor tersebut, lingkungan nasabah merupakan preferensi yang sangat menentukan bila dibandingkan dengan indikator lain. Kemudian menyusul kesesuaian dengan keyakinan dan lokasi bank di urutan kedua. Selanjutnya konsep bagi hasil dan pemahaman agama berada di urutan ketiga dan keempat. Sebaliknya faktor manfaat ekonomi berada urutan terakhir. Hal ini mengindikasikan bahwa manfaat ekonomi bukanlah pertimbangan penting bagi nasabah dalam memilih produk pembiayaan bank syariah tersebut.

Kedua, perbedaan jenis kelamin, umur, status perkawinan dan tingkat pendidikan tidak menyebabkan adanya perbedaan preferensi nasabah dalam memilih produk pembiayaan Bank Aceh Syariah. Preferensi nasabah dalam memilih produk pembiayaan bank tersebut hanya berbeda berdasarkan pekerjaan (wirausahawan/pengusaha dan bukan wirausahawan/ pengusaha) serta berdasarkan pendapatan rata-rata per bulan.

\section{Saran}

Berdasarkan kesimpulan yang telah diuraikan, yang menjadi preferensi utama bagi nasabah dalam memilih produk pembiayaan Bank Aceh Syariah di kota Banda Aceh adalah lingkungan nasabah itu sendiri, kemudian menyusul kesesuaian dengan keyakinan dan pemahaman agama. Sementara manfaat ekonomi tidak begitu dominan dalam membentuk preferensi nabasah, hal ini berarti bahwa manfaat ekonomi yang diterima masyarakat dengan manfaatkan produk pembiayaan syariah tersebut tidak begitu berbeda dengan manfaat ekonomi yang mereka terima bila memanfaatkan layanan kredit dari bank konvensional.

Berdasarkan kesimpulan itu, maka direkomendasikan agar Bank Aceh Syariah Banda Aceh harus konsisten dalam menjalankan prinsip-prinsip syariah dalam kegiatan operasional perbankan, terutama dalam produk pembiayaan syariah itu sendiri. Penetapan bagi hasil yang kurang berpihak 
kepada nasabah pembiayaan akan dapat menimbulkan persepsi bahwa produk pembiayaan syariah juga tidak jauh lebih baik bila dibandingkan dengan produk pembiayaan pada bank konvensional.

Selain itu, Bank Aceh Syariah Banda Aceh dipandang perlu juga melakukan sosialisasi yang lebih intensif berhubungan dengan produk pembiayaan syariah yang ditawarkan kepada masyarakat. Hal ini dimaksudkan agar mereka lebih memahami kelebihan dan kekurangan produk tersebut bila dibandingkan dengan produk yang ditawarkan oleh bank konvensional.

\section{DAFTAR PUSTAKA}

Gerrard dan Cunningham, J.B. 1997. Islamic Banking: A Study in Singapore. International Journal of Bank Marketing. Vol. 15, No. 6, hal. 124137.

Khoirudin, M. 2005. Preferensi Nasabah terhadap Produk Pembiayaan (Mudharabah, Musyarakah, dan Murabahah) Bank Syariah. Tesis. Yogyakarta: UIN Sunan Kalijaga.

Koo, L.C., Tao, F.K.C. dan Yeung, J.H.C. 1999. Preferential Segmentation of Restaurant Attributes through Conjoint Analysis. International Journal of Contemporary Hospitality Management. Vol. 11, No. 5, hal. 242-250.

Kurniati. 2012. Analisis Persepsi dan Preferensi Nasabah Muslim dan
Nasabah Non Muslim terhadap Keputusan Memilih Perbankan Syariah di Provinsi Daerah Istimewa Yogyakarta. Jurnal Ekonomi Syariah Indonesia. Vol. 2, No. 2, hal. 251-276.

Majid, A.S. dan Zulhanizar, S. 2016. The Patronage Behaviour of Islamic Bank's Customers: Empirical Studies in Aceh. Al-Iqtishad: Jurnal Ilmu Ekonomi Syariah (Journal of Islamic Economics). Vol. 8, No. 2, hal. 201-212.

Metawa dan Almosssawi, M. 1998. Banking Behavior of Islamic Bank Customers: Perspective and Implication. International Journal of Bank Marketing. Vol. 16, No. 7, hal. 212235.

Naser, A.J. dan Al-Khatib, K. 1999. Islamic Banking: A Study of Customer Satisfaction and Preferences in Jordan.

The International Journal of Banking Marketing for the Financial Services Sector. Vol. 17, No. 3, hal. 25-38.

Rezwan, F., Shabnaz dan Shajahan, B. 2015. Analyzing the Attitude of Customers towards Islamic Banking and Conventional Banking in Bangladesh. Journal of Economics and Finance. Vol. 6, No. 5, hal. 24-29.

Simamora, B. 2004. Panduan Riset Perilaku

Konsumen. Jakarta: PT. Gramedia Pustaka Utama. 